3 variaciones sobre el silencio

Alfredo Schechtman*

\title{
El Silencio
}

La palabra tarda

el vacío llena

la angustia

plena

Silencios

La palabra tarda

el vacío se llena

de angustia

plena

Silencio

Las palabras tardan

la angustia llena

el vacío

pleno

* Alfredo Schechtman é médico, Mestre em Medicina Social e poeta. 